w zbawieniu i stworzeniu ${ }^{40}$. Dlatego, gdy "stworzenie skazuje siebie na oddalenie od Ojca, On (...) dosięgnie je i otoczy swoją jeszcze większą miłością: posyłając Syna „Stwórcę” (któremu towarzyszy Duch absolutnej miłości między Nim i Ojcem) (...) przyjmując je znów w tym totalnym posłuszeństwie, z jakiego się zrodziło" ${ }^{41}$. Stworzenie znajduje wypełnienie w Zmartwychwstaniu, które jest źródłem radości świata: Deus, qui, per resurrectionem Filii tui Domini nostri Jesu Christi, mundum laetificare dignatus es". Akt stwórczy nie jest przypadkowy. Bóg pamięta o swoim dziele i wciąże nim kieruje, aby ludzkość i świat cały doprowadzić do doskonałej jedności z Sobą - to jest cel całej historii zbawienia. Najdoskonalszą jedność poznajemy w Trójcy Przenajświętszej, która przez dzieło stworzenia, zbawienia i uświęcenia, objawia się nam w czasoprzestrzeni Kościoła.

Koszalin

KS. ANDRZEJ KORPUSIK

Ks. Kazimierz Hola

\title{
TAJEMNICA EUCHARYSTII W ASPEKTACH DZIEJOZBAWCZYCH I DOGMATYCZNYCH
}

1. EUCHARYSTIA DAREM ZOBOWIAZZUJAZCYM

$\mathrm{Za}$ ideę przewodnią niniejszych rozważań poświęconych pewnym wybranym - jak zobaczymy dalej - aspektom teologicznym tajemnicy Eucharystii w swietle nowszej refleksji teologicznej obieramy prawdę wypowiedzianą przez Jana Pawła II o darze Eucharystii. Jest ona mianowicie, jak powiada Papież, ,największym darem, jakim w porządku laski i sakramentu Boski Oblubieniec obdarzyl i stale obdarza swoją Oblubienice - Kościół". A jest to dar, który tak bardzo nas zobowiązuje. „Zawsze najgłębiej zobowiązuje dar mówi dalej Papież - gdyż przemawia on nie tyle mocą ścisłego uprawnienia, ile mocą osobistego zawierzenia i tak - domaga się zaufania i wdzięczności. Eucharystia jest takim właśnie darem, takim dobrem" 1.

${ }_{40}$ T. Wilski, Stworzenie, w: Z. Pawlak (red), Katolicyzm $A-Z$, Poznań 1982, 348.

$41 \mathrm{~S}$ i c a ri, art. cyt., 18.

1 Jan Pawe II, List do wszystkich biskupów Kościoła o tajemnicy $i$ kulcie Eucharystii $z$ 24. II. 1980; zob. „Notificationes e Curia Metropolitana Crancoviensi" Nr 5-6, 1980 s. $115 \mathrm{n}$. 
Rozwijając myśl Ojca świętego postawmy z kolei pytanie, w jaki sposób ów dar niezwykły, dar Najświętszej Eucharystii, nas zobowiązuje. Wielorakie zobowiązania, jakie pociąga za sobą Eucherystia w calym życiu wierzącego chrześcijanina to odrębny i jakże szeroki temat. Tutaj jednak pragniemy zwrócić uwage na szczególny rodzaj zobowiązania, jaki nakłada dar Eucharystii na teologię. Można powiedzieć, że najwyższym zadaniem teologii jest służba przedwiecznemu Slowu Bożemu i słowu objawionemu w urzeczywistnianiu wypiywającego z nieskończonej miłości Bożej planu i clekretu zbawienia człowieka, w konsekwencji zaś jest to również służba Kościolowi i człowiekowi. Celowi temu może teologia służyć w rozmaity sposób. Można by zaryzykować twierdzenie, że służą mu wszelkie, prowadzone ,w dobrej wierze", a zatem także i najbardziej zawikłane i abstrakcyjne spekulacje. Ale chyba służą mu znacznie lepiej i skuteczniej dociekania przybliżające wierzącemu, a niekiedy wątpiącemu człowiekowi tajemnice Boże i przez to ułatwiające mu zarazem nawiązanie bliższego i żywszego kontaktu $z$ miłującym i prowadzącym nas do zbawienia Bogiem. I temu celowi pragnie przede wszystkim, w jakiejś skromnej mierze, służyć i niniejsze rozważanie.

$\mathrm{Z}$ bogatego skarbca współczesnej refleksji teologicznej na temat Eucharystii wybieramy w obecnym rozważaniu dwa kierunki i zagadnienia. Pierwszy z nich to próba ukazania Eucharystii na plaszczyźnie dziejów zbawienia jako uczty Chrystusa-Gospodarza ze swoją wspólnotą, która to uczta w liturgicznym obrzędzie staje się żywą pamiątką uobecniająca Jego dzieło zbawcze. Drugi zaś z tych kierunków usiłuje nam przybliżyć rozumienie Eucharystii w tym, co wyraża w niej najbardziej tajemnicę, a mianowicie stara się w mierze dostępnej ludzkiemu poznaniu odpowiedzieć na pytanie: w jaki sposób Chrystus staje się obecny w Eucharystii i w jaki sposób jest W niej obecny?

\section{OSTATNIA WIECZERZA W PERSPEKTYWIE DZIEJÓW ZBAWIENIA}

Eucharystia sprawowana przez Jezusa przy Ostatniej Wieczerzy znajduje się w centrum dziejów zbawienia: wieńczy bowiem i zamyka $z$ jednej strony epokę dziejćw zbawczych przebiegających od stworzenia człowieka do odkupienia, w szczególny zaś sposób kończy okres starotestamentalnego Starego Przymierza, z drugiej natomiast strony ustanawia Nowe Przymierze i rozpoczyna jego dzieje, mające trwać aż do momentu eschatologicznego odrodzenia. Stąd wynikają wielorakie powiązania Ostatniej Wieczerzy w jej eucharystycznej treści zarówno ze Starym jak i z Nowym Przymierzem. Przypatrzmy im się bliżej.

Ostatnia Wieczerza jest niezwykłym wydarzeniem, którego istotna treść nie ma podobnego sobie przykładu. Pozostaje ona jednak w 
związku $z$ wieloma innymi wydarzeniami w życiu Jezusa. Przede wszystkim zaś pozostaje w związku z ogólną Jego praktyką posiłków, stanowiąc swoistego rodzaju zakończenie tej praktyki. Praktykowanie przez Jezusa codziennej wspólnoty stołu ze swymi bliskimi, a także zasiadanie niekiedy do posiłków z celnikami i grzesznikami miało swą wymowę. Wspólnota stołu oznaczała solidarność ze współbiesiadnikami. Jezus jako wysłannik Boga okazywał i wyrażał w ten sposób zainteresowanie Boga $w$ odniesieniu do nich. Jezusowa praktyka posiłków miała też szczególny charakter mesjański, bowiem Jego obecność wśród ludzi na podobieństwo obecności pana młodego wśród gości weselnych ( $\mathrm{Mk} 2,19)$ była eschatologicznym znakiem, że przybliżyło się i jest obecne w Jego działaniu Królestwo Boże. Obecność Jezusa była zarazem zapowiedzią i zadatkiem eschatologicznego posiłku weselnego, jaki według relacji Mateusza wybrani mają spożywać w królestwie niebieskim (Mt 8, 11; 22, 1-14; 25, 1-13). Właściwym posiłkiem mesjańskim jest jednak cudowne rozmnożenie chleba i ryb oraz nakarmienie nimi wielotysięcznej rzeszy. W wielu szczegółach tego wydarzenia mamy już bliskie podobieństwo do Ostatniej Wieczerzy, w której Jezus jako nowy Mojżesz celebruje Eucharystie, swój nowy posiłek Przymierza i pozostawia go jako zapis testamentalny tym, którzy należą do Niego.

Kolejny rys Eucharystii to jej powiązanie z żydowską Paschạ. Warto tu wspomnieć, że dyskutowano już wiele i nadal się dyskutuje czy Ostatnia Wieczerza była prawdziwą wieczerzą paschalną. Nie wchodząc bliżej $w$ ten problem ${ }^{2}$ podsumujemy go tu krótkim stwierdzeniem: z jednej strony zdaje się nie ulegać wątpliwości, że Ostatnia Wieczerza $w$ zewnętrznym przebiegu spełnianych czynności. była prawdziwą wieczerzą paschalną. Jednakże jeszcze bardziej oczywistym jest że Jezus posługując się niejako jej oprawą włożył w nią nową treść niepomiernie przekraczającą ideową treść starotestamentalnej Paschy, dlatego też słusznie nazywamy Ostatnią Wieczerzę Nową Paschą.

Kolejne tedy, lecz o wiele irudniejsze pytanie brzmi teraz: na czym zasadza się ta nowa treśé, wyrażająca istotny sens Eucharystii? Usiłując $\mathrm{w}$ dalszym ciągu wnikać $\mathrm{w}$ ową treść na płaszczyźnie dziejozbawszej powróćmy jeszcze na moment do powiązań Ostatniej Wieczerzy z żydowską ucztą paschalną. Otóż istotne obrzędy Ostatniej Wieczerzy stanowił podwójny aspekt błogosławienia oraz podanie do spożycia konsekrowanego chleba $\mathrm{i}$ wina. W gestach tych Jezus nawiązał do typowych żydowskich gestów spełnianych w czasie posiłku. Z obrzędów paschalnej wieczerzy Jezus wybrał słowo błogosławienia berakha i centralny gest podania darów posiłku dla anamnezyjnej celebracji swego dzieła zbawczego, nadając zarazem tym gestom

2 Zob. K. Hola, Paschalny charakter Ostatniej Wieczerzy a data smierci Jezusa, RBL 1 (1985) $41-45$. 
szczególny, nowy sens i nową treść. Ujmiemy tę treść w trzech kolejnych rysach.

Celebracja Ostatniej Wieczerzy była mianowicie najpierw proklamacją śmierci Jezusowej i zapowiedzią nowej rzeczywistości zbawczej. Jezus proklamuje, ogłasza i zarazem aktualizuje, wprowadza w czyn nową, eschatologiczną rzeczywistość zbawczą, a wprowadza ją przez swą śmierć. Jakże dobitnie wyrażaja to Jego słowa: ,To jest Ciało moje za was wydane - To jest Krew moja za was przelana". Słowa te, mające w pewnej mierze swój prawzór w Izajaszowym opisie cierpień Sługi Pańshiego zapowiadają nadchodzącą śmierć Jezusa jako męczeńską ofiarę życia, pojętą jako uniwersalistyczną śmierć okupująca. Tak pojęta ofiara w Markowym określeniu ,krew przymierza" (Mk 14, 24) otrzymuje jeszcze kolejny wymiar w nawiązaniu do przedstawionej w Księdze Wyjścia, oddzielonej od ciała krwi jako darze ofiarnym, tak że śmierć Jezusa jako kultyczne zabicie na ofiarę otrzymuje również cechę kultyczną.

Następnym rysem posiłku Ostatniej Wieczerzy jest charakter symboliczny, mianowicie akt ten symbolizuje zbawcze dzieło Jezusa. Aby sformulowanie takie nie wywołało obaw czy wątpliwości dodajmy tu od razu, że symbolizm w wyclarzeniu Ostatniej Wieczerzy jest niezaprzeczalnym faktem. W tym jednak sedno, że symbolizm to tylko jeden z wymiarów, bowiem - jak zobaczymy dalej - wydarzenie Ostatniej Wieczerzy ma nadto jeszcze inny, znacznie głębszy wymiar: dary posiłku i ich eucharystyczna celebracja nie tylko symbolizują, lecz i utcżsamiają się w pewien sposób ze zbawczą osobą Jezusa, a zarazem z Jego dziełem zbawczym.

Otóż symbolicznymi aktami w Ostatniej Wieczerzy sa czynności błogosławienia i podania darów posiłku. W gestach tych Jezus symbolizuje i aktualizuje swą nadchodzącą śmierć. Teologia mówi w zwiazku $z$ tym o ich anamnezyjnym i ofiarniczym charakterze. Zauważmy tu, że słowo anámnesis użyte w nakazie powtarzania eucharystycznej uczty $w$ opisach Eukasza i Pawła określa pojęcie pochodzące z żydowskiego obrzędu Paschy. Jest to tłumaczenie hebrajskiego zikkaron stanowiącego centralne pojęcie starotestamentalnej teologii kultu. A istotna treść ukryta pod tym pojęciem jest taka, że byla to, po pierwsze, celebracja upamiętniająca przeszłe wydarzenia, tj. wyjście z Egiptu. Lecz nie tylko upamiętniająca, ale, po wtóre - i co istotniejsze - zarazem w jakiejś mierze urzeczywistniająca aktualne odniesienia do owego wydarzenia. „Anamneza”, , ,anamnezyjny" są tedy, jak widzimy, pojęciami o bardzo bogatej treści i dlatego są dla nas niezwykle pomocne dla wyrażenia treści Eucharystii. Niestety jednak brak nam w nowożytnych językach adekwatnego im odpowiednika; musimy się tedy uciekać do dłuższego, przynajmniej dwuwyrazowego określenia, np. „pamiątka uobecniająca".

Wróćmy jednak do Ostatniej Wieczerzy i podsumujmy nasze rozważania o jej symbolicznym rysie stwierdzeniem, że charakter sym- 
boliczny ma swoja szczególną wymowę w gestach podania do spożycia darów posiłku, które symbolizują wydanie Jezusowego Ciała na śmierć za ludzi. Dodajmy jeszcze, że Jezusowe dzieło zbawcze jest aktem podwójnego wydania, mianowicie wydania w odniesieniu do Ojea i wydania w odniesieniu do ludzi.

Dochodzimy wreszcie do trzeciego, najistotniejszego rysu Ostatniej Wieczerzy, polegającej, jak wzmiankowaliśmy, na tym, że dary posilku utożsamiają się ze samą zbawczą osobą Jezusa.

Zwróćmy najpierw uwagę, że nową treść darów posiłku Ostatniej Wieczerzy wyraża Jezus w słowach stanowiących pewien analogat do słów błogosławienia w żydowskiej wieczerzy paschalnej. Oświadcza mianowicie, że chleb, który podaje do spożycia, jest̂ Jego Ciałem, a o zawartości kielicha podanego do wypicia mówi; że, jest „Nowym Przymierzem w Jego Krwi" (1 Kor 11, 24; Łk 22, 20), względnie „Krwią Przymierza wylaną za wielu” (Mt 26, 28; Mk 14, 24). Zauważmy, że pojęć „ciało" i ,krew” nie należy rozumieć dwudzielnie, jako części człowieka. W sensie antropologii semickiej nie mówi się, że człowiek ma ciało, lecz ,jest ciałem”. Greckie soma, stanowiące odpowiednik aramejskiego basar, względnie guph, jakim posłużył sie prawdopodobnie Jezus, oznacza tedy żywą, konkretną osobę. Podobnie jest ze słowem haima, tzn. krew. Jego hebrajski odpowiednik dam oznacza w Starym Testamencie często krew $w$ znaczeniu wydarzenia, tj. przelanie krwi.

Zawartość kielicha Ostatniej Wieczerzy proklamuje Jezus jalko Nowe Przymierze w Jego Krwi. Mamy tu znów jakże bogate w treś w Starym Testamencie pojęcie przymierza. Nawiązując do niego Jezus nadaje jednak wyrażeniu „Krew Przymierza" nowy, niepomiernie bogatszy sens, oznajmiając, że Ciało Jego zostaje wydane, a. Krew zostaje przelana. W słowach tych Jezus nawiązując do Izajasza stosuje do swej osoby pojęcie cierpiącego Sługi Pańskiego. Jezus jest mianowicie Sługą Bożym umierającym śmiercią okupującą, który zmierza jednak do eschatologicznego zwycięstwa.

Nasze dociekania nad istotną treścią Ostatniej Wieczerzy w jej wymiarze dziejozbawczym, podsumujmy znów wnioskiem: Jezus utożsamia dary posiłku ze swoją ofiarująca osobą. W posiłku tym, w eucharystycznej uczcie, daje On nam siebie samego jako pokarm. do spożycia ${ }^{8}$.

\section{DOGMATYCZNE UCHYLANIE RAZBKA TAJEMNICY}

Pora przejść teraz do drugiego, zapowiedzianego we wstępie punktu rozważań, tj. do refleksji nad pytaniem, w jaki sposób Chry-

8 Por. J. Betz, Eucharystie als zentrales Mysterium, w: „Mysterium Salutis" IV, 2, s. 195-203. 
stus staje się obecny i w jaki sposób jest obecny w Eucharystii. Mamy tu do czynienia z zagadnieniami par execllence dogmatycznymi, nad którymi, jak wiemy, przez długie wieki głowiła się teologia i które zostały niejako skrystalizowane w nauczaniu kościelnym, przede wszystkim zaś w dogmatycznych orzeczeniach Soboru Trydenckiego. Warto tu zauważyć, że wielu teologów uprawiających w naszych czasach teologię Eucharystii zatrzymuje sį w swych docickaniach na płaszczyźnie dziejozbawczej, której istotne rysy ukazaliśmy w pierwszej części naszych rozważań. Tak czyni np. głos̉ny przedstawiciel wspólnoty w Taizé Max Thurian, który powiada: ,Jak do tego dochodzi, że Chrystus również cieleśnie może być obecny w Eucharystii, to tajemnica, to dzieło Ducha Swiętegro, którego Kościól nie potrafi okreslić przy pomocy pojęć" ". Ale z takim stanowiskiem nie można się zgodzić. Prawdą jest, że tajemnicy wiary nie możemy zgłębić całkowicie, tzn. poznać jej wyczerpująco, bez reszty, ale nie znaczy to, że nic z niej nie możemy poznać czy wyrazić w pewnej mierze przy pomocy dostępnych nam pojęć. Gdyby tak było, to Kościól nie powinien formułować dogmatu o przeistoczeniu ani o rzeczywistej, substancjonalnej obecności Chrystusa w Eucharystii. Tymczasem właśnie już te, zdobyte przy pomocy teologii aspekty uchyliły w pewnym stopniu rąbka tajemnicy w dostępnych w czasie definiowania dogmatów pojęciach, nam zaś pozwalają, a nawet zmuszają nas do dalszego zgłębiania tej tajemnicy przy pomocy pojęć dla nas dostepnych i zrozumiałych.

Formuły dogmatyczne Soboru Trydenckiego o transsubstancjacji i substancjalnej obecności Chrystusa w Eucharystii możemy z pewnego punktu widzenia traktować jako ramy pojęciowe, wyznaczające w ówczesnych, znanych i dostępnych kategoriach myślowych przede wszystkim granice między ortodoksją a nieortodoksją katolicką. Eatwiej jest przy ich pomocy ustalić, co nie leży w granicach ortodoksji, tak np. nie leży w nich sprowadzanie Eucharystii do roli czystego symbolu, jak to czynili symboliści różnych czasów; nie mieści się też w nich pojmowanie Eucharystii jako prostego wspomnienia (nuda commemoratio) - jak to określił Sobór Trydencki ${ }^{5}$ - jedynej, krwawej ofiary dokonanej jeden raz przez Chrystusa na krzyżu. O wiele trudniej jest natomiast odpowiedzieć jaka właściwa treść mieści się wewnątrz owych ram trydenckich formul dogmatycznych: co stanowi ową substancję chleba i wina, która przemienia się w Ciało i Krew Chrystusa i na czym ta przemiana polega? I czy przy pomocy naszych pojęć możemy bliżej uprzystępnić sobie sposób obecności Chrystusa pod postaciami eucharystycznymi? Po II wojnie światowej bo ten okres bliżej nas tu interesuje - najpotężniejsze urnysły

4 Cytuję za: A. Gerken, Teologia Eucharystii, Warszawa 1977, s. 186.

5 DS 1753. 
teologów zaczęły się zmagać z wymienionymi problemami. Nie sposób byłoby tu referować rezultaty ich wysiłków. Ale może celowym będzie ograniczyć się do podsumowujących wniosków i wskazać przykładowo na jedną próbę interpretacji, pozwalającą nam dojrzeć w Eucharystii coś, czego nie dostrzegano w minionych stuleciach. Bo to może znów nowe światło, ułatwiające nam zbliżenie do Chrystusa i Jego zbawczego dzieła!

Punktem wyjścia dla powojennych prób tłumaczenia przeistoczenia eucharystycznego i sposobu obecności Chrystusa w Eucharystii stało się nowe, centralne dla całości zagadnienia pojęcie substancji. Poszukiwania tego nowego pojęcia związane były $w$ początkach z rozwojem nauk przyrodniczych i z filozofią przyrody. Powstała w związku $z$ tym, tzw. teoria fizyczna tłumaczenia Eucharystii. Ale nie wytrzymała próby. Prędko zrozumiano, że teologia nie może oczekiwać wielkiej, czy raczej bezpośredniej pomocy od nauk przyrodniczych, gdyż posluguje się ona pojęciami nie podpadającymi pod ich kompetencje. Druzgocącą krytykę „teorii fizycznej” przeprowadził tuż po drugiej wojnie światowej K. Rahner. Umysły teologów zwróciły się następnie ku tzw. teorii metafizycznej. Teoria ta usiłuje pojmować substancję $\mathrm{w}$ szerokim i ogólnym znaczeniu jako istote, $w$ odróżnieniu od warstwy zjawiskowej rzeczy. Ma to niewatpliwie swoje zalety, ale nie zadowala już dzisiejszych teologów. Takie bowiem rozumienie substancji umożliwia wprawdzie odróżnienie metafizycznej płaszczyzny substancji od empirycznej płaszczyzny postaci i wystarcza do wyrażenia wiary Kościoła tak, jak została ona wyrażona w XVI wieku $\mathrm{w}$ dogmacie przeistoczenia. Nie jest to jednak rozumienie zadowalające dla refleksji teologicznej, która chce prawdy wiary zglębiać, i coraz lepiej wyrażać. Ponadto może narazić na zarzut, że powoływanie się na niejasną i bliżej nieokreśloną płaszczyznę metafizyczną może stwarzać wrażenie ucieczki w odległy, fantazyjny świat metafizyki. Najwybitniejsi teologowie poczęli wówczas szukać nowego, bardziej odpowiadającego i przystępniejszego dzisiejszemu człowiekowi pojęcia substancji i jego zastosowania do prób nowej interpretacji transubstancjacji eucharystycznej i sposobu obecności Chrystusa w Eucharystii. Posługują się oni m. in. takimi pojęciami jak: pojęciem substancji antropologicznej, rozumianej przez odniesienie do człowieka, ukonstytuowanej przez kontekst odniesienia, dalej pojęciem ustanowienia nowej funkcji znaku i symbolu, wreszcie funkcji odniesienia do nowego celu ${ }^{6}$. W próbach tych widoczne są usiłowania zastosowania do tłumaczenia tajemnicy Eucharystii kategorii pojęciowych zaczerpniętych $\mathrm{z}$ nowszych kierunków filozofii, w szczególności filozofii egzystencjalnej i fenomenologii. I tu nasuwa się pytanie: czy takie postępowanie jest słuszne? Odpo-

6 Zob. G. Hintzen, Die neuere Diskussion über die eucharistische Wandlung, Frankfurt am Main 1976. 
wiedź może być w zasadzie tylko pozytywna. Przypomnijmy tu dawną maksymę: Philosophia ancilla theologiae. Ostatecznie cały świat ma służyć Bogu i Słowu Wcielonemu. Służy Mu Kościół i jego instytucje. Słowu Wcielonemu i słowu objawionemu - jak podkreśliliśmy na wstępie - służy w szczególny sposób teologia, posługując się na miarę swych potrzeb owocami dociekań filozofii, w szczególności dociekań nad strukturę otaczającej nas rzeczywistości, strukturą ludzkiego bytowania, myślenia, języka. Lecz żaden system filozoficzny nie ma tu monopolu. Jest przy tym rzeczą ewidentną, że kierunki i pojęcia starzeją się, jak wszystko zresztą na tym świecie oprócz obecnego w nim pierwiastka Bożego starzeje się i zmienia, na miejsce zaś tego co stare, rodzi się nowe. Przed dzisiejszą teologią stoi więc nie tylko możliwość, ale obowiązek i pótrzeba chwili, by usiłować wprzęgnąć w służbę Przedwiecznego Słowa i Jego tajemnic również i to, co wnoszą do myśli współczesnej rezultaty dociekań filozofów i myślicieli.

Od tych ogólnych refleksji wróćmy jeszcze raz do nowych prób interpretacji Eucharystii i zastanówmy się na przykładzie zapowiedzianego jednego nowszego pojęcia czy pozwala nam ono głębiej wniknąc w tę tajemnicę wiary i przybliżyć ją sobie. Jest to mianowicie odkryte przez nowszych teologów, a nieznane teoriom scholastycznym pojęcie obecności osobowej. Zostało ono mocno skrytykowane przez przedstawicieli bardziej tradycyjnej teologii. Czy jednak słusznie? Co wyraża to pojęcie w zastosowaniu do eucharystycznej obecności Chrysiusa? Zwolennicy obecności osobowej powiadaja - i to chyba słusznie - że Chrystus obecny jest w Eucharystii nie jak jakaś rzecz, lecz w sposób osobowy, jako osoba i w odniesieniu do osób. Obecność taką należy pojmować, zdaniem ich, w sposób, w jaki miłość może być obecna, mianowicie jako dobrowolne samodarowanie się podmiotu ,ja" podmiotowi, „ty" ?. Jakkolwiek obecność osobowa dochodzi do najpelniejszego wyrazu w obecności fizycznej, somatycznej, w jakiej realizuje się pragnienie łączności, to jednak pragnienie takie jest ponad czasem i przestrzenią: nawet bowiem dłuższa rozłąka osób bliskich sobie, miłujących się, nie musi osłabiać ani zrywać ich łączności, lecz może nawet ją pogłębiać. Znamy z doświadczenia takie przypadki. Otóż pojęcie takiej obecności pozwala nam rzucić szczególne światło na obecność Chrystusa w Eucharystii. Postawą jej jest Jego śmierć, odejście do Ojca, rozstanie się ze swymi bliskimi, a więc pewna nieobecność. Ale związana jest z nią duchowa obecność Chrystusa w Ǩościele, wedle Jego słów: „Odchodzę i przyjdę znów do was" ( $J$ 14, 28). Ta duchowa obecność wydanego na śmierć Jezusa umożliwia Mu właśnie osobową obecność w sakramencie Eucharystii.

7 Por. J. Ratzingen, Das Problem der Transsubstantiation und die Frage nach dem Sinn der Eucharistie, ThQ 147 (1967) 154. 
Takiemu pojmowaniu obecności Chrystusa w Eucharystii postawiono wiele zarzutów. M. in. i zarzut, że niegodni nie spożywaja w takim razle Eucharystii, innymi słowy że sakrament dochodzi tylko wtedy do skutku, gdy przyjmuje go chrześcijanin, który jest tego godny. Ale zarzut ten łatwo jest odeprzeć. Bowiem xówinież i obecność, w której istotnym jest odniesienie osobowe, czyli obecność nàstawiona na partnera, może być jako taka niezależna od rzeczywistego zachowania się partnera. Ten, kto ofiaruje dar, jest obecny osobowo nawet wtedy, gdy dar nie zostaje w ogóle przyjęty, albo nie zostaje przyjęty $\mathrm{z}$ wdzięcznością ${ }^{8}$. Możemy to również wyrazić znanym i stosowanym chętnie $w$. katechetyce, wywodzącym się od E. Schillebeckxa pojęciem spotkania człowieka z Chrystusem w sakramencie, w danym przypadku w sakramencie Eucharystii. Spotkanie - to na wskroś wydarzenie osobowe, gdyż może ono nastąpić tylko między osobami. Otóż Chrystus wychodzi w komunii sakramentalnej człowiekowi na spotkanie i ofiaruje mu zbawienie. A człowiek wychodzący na to spotkanie może ów dar przyjąć, albo też postępując niejako pół kroku w przód, obrócić się wstecz, daru nie przyjąć i odejść od Chrystusa.

Wydaje się, że pojęcie obecności osobowej rzuca nam nowe światło na tę tajemnicę, co nie znaczy, że ma ono całkowicie zastąpić pojęcie obecności substancjalnej i somatycznej. Ma je raczej dopełniać. Pozwala nam ono lepiej rozumieć to, co tak bardzo podkreśla dzisiejsza teologia, iż obecność Chrystusa w Eucharystii to przede wszystkim obecność zbawcza. Bo staje się On obecny w Eucharystii, by nas zbawić. Znaczy to również, że obecność ta nie jest statyczna, bierna, lecz aktywna, dynamiczna, gdyż zjawiając nas przecié் Chrystus ciągle jest czynny, ciągle działający.

Dzialanie zbawcze Chrystusa w Eucharystii znajduje najpełniejszy wyraz w owocach uczestniczenia naszego w uczcie eucharystycznej, czyli w skutkach komunii sakramentalnej. I to działanie pozwala nam również lepiej rozumieć pojęcie obecności osobowej. Teologia sprowadza szczegółowe, rozliczne skutki Komunii św. do jednego, bardziej ogólnego, jakim jest doskonalsze, ściślejsze zjednoczenie całego człowieka z Chrystusem i z Jego Mistycznym Ciałem - Kościołem. Zasadą, która to zjednoczenie urzeczywistnia jest miłość Boga i bliźniego. Otóż, jak widzieliśnyy, teologowie pojmują właśnie obecność osobową na sposób, w jaki obecna może być miłość obdarowująca, urzeczywistniana między podmiotami stanowiącymi osoby; zatem taka właśnie obecność osoby wcielonego Syna Bożego w szczególny sposób znajduje wyraz w Eucharystii.

Kraków

KS. KAZIMIERZ HOEA

8 Por. A. Gerken, dz. cyt., s. 193. 